\title{
From Victims of Trafficking to Freedom Fighters: Rethinking Migrant Domestic Workers in the Middle East ${ }^{1}$
}

\begin{abstract}
Throughout the Middle East migrant women are employed to work in people's homes. While some experience good working relations with employers, others experience forms of abuse and labour coercion. This chapter evaluates critically different ways that system of unfree labour has been variously described and analysed as a form of 'contract slavery', 'debt bondage' and 'trafficking'. It also shows how migrant women who describe themselves as 'freelancers' exit their original employer's home both to escape that relation and in hopes of securing a better situation outside of the regular system of employment. Freelancing is more than simply a form of resistance. Rather, women who work as freelance migrant domestic workers challenge directly that state enforced control over their mobility and are on the vanguard of those migrants who are seeking through their own actions to effect social change.
\end{abstract}

Key words: migrant domestic workers, contract slavery, debt bondage, trafficking, freedom

\section{Biographical note:}

Mark Johnson is Reader in Anthropology at Goldsmiths, University of London. His research interests and writing are focused broadly around the issues of gender/sexuality, landscape and material culture, movement and transnationalism. His previous research includes AHRC funded investigation of the place of religion in the experiences of Filipino migrant workers in the Middle East and Saudi Arabia in particular. Current British Academy funded research investigates ordinary people's awareness of and perceptions about different sorts of surveillance they encounter during their travels and explores the connections between care and control in processes of watching and being watched.

\section{Introduction}

Throughout the Middle East several million migrant women, from Asia and Africa especially, are employed routinely to work in people's homes as cooks, cleaners and caregivers for

\footnotetext{
${ }^{1}$ Author Accepted Manuscript. In Revisiting Slavery and AntiSlavery: Towards A Critical Analysis, Laura Brace and Julia O'Connell Davidson (eds.), London: Palgrave Macmillan. 2018, 179 - 207. ASIN: B07H3NBNTN: ISBN 978-3-319-90622-5 - https://www.springer.com/de/book/9783319906225
} 
children and older people. While some experience good working relations with employers, others experience forms of abuse and labour coercion. More specifically, migrant women working in the home may be confronted by citizen employers who, enabled by the state, convert what is nominally a contractual relationship of wage labour into one construed as indebtedness on the part of the employee and beneficence on the part of the employers.

Responding to that, migrant women who describe themselves as 'freelancers', exit their original employer's home both to escape that relation and in hopes of securing a better situation outside of the regular system of sponsorship. Defined variously by some as contract slavery or bonded labour, we now have a reasonable understanding of the state system of migrant labour sponsorship known commonly as the kafala system that produces and enables this particular form of unfree labour and of its consequences for many migrants, female domestic workers in particular, in that part of the world. We have much less knowledge about or understanding of 'freelancing' and 'freelancers'. What does freelancing entail and what does it mean to describe oneself as a freelancer in a situation of severe constraint?

The term freelancing reportedly originates in the early $19^{\text {th }}$ century and was used initially in English literature to designate the free lance knights and mercenaries of medieval Europe, those who had escaped 'lordship', owned their own armour and exercised, 'de facto independence and freedom of movement', even if in practice their situation was far more constrained, and as the notion of mercenary suggests, also were sometimes regarded as morally suspect (Scammel 1993). In contemporary times, the term, including its recent variation 'elancer', is now frequently associated with a growing number of 'contract professionals' engaged in contingent work including artists, writers and computer engineers (Osnowitz 2010).

In beginning to think about the possible meanings of freelancing as used by migrant domestic workers in the Middle East especially, I start with Laura Brace's work (2002, 2010, 2013) who draws on Wood's (1990: 242) use of the term 'freelance hustler' to evoke $18^{\text {th }}$ and $19^{\text {th }}$ century gendered ideologies about morally suspect and disreputable persons engaged in inappropriate market behaviour, such as gamblers and women. Good liberal subjects were men who not only owned their labour but also were ethically self-possessed and exhibited public virtue. Women, by contrast, did not fully own their labour and were considered virtuous only to the extent that they concerned themselves primarily with the family and the management of her husband's private property. Those women who participated in the market were deemed to be self-seeking women who repudiated the bonds and obligations of family and civil society and became chancers, vagabonds and 'working women'. Extending that 
work Brace (2013) argues that a contemporary analogy of those 'freelance hustlers' are to be found in discourses that simultaneously constrict and deny some groups of 'unskilled', 'economic' migrants, women especially, the possibility of citizenship and ascribes that lack of belonging to their perceived moral failings as people who have through choice or compulsion cut their ties with families, place and cultures in order to pursue a better life elsewhere.

The discourses that produce the precarious and morally suspect migrants that Brace seeks to unravel are certainly resonant with the discourses that shape and attach to the women who are migrant domestic workers in the situations I am concerned with here, especially those who openly challenge the systems of unfree labour under which they work. On the one hand, migrant domestic workers are often regarded as being driven by necessity to take on work routinely cast as both dirty and degrading. On the other hand, migrant domestic workers are also, as Brace suggests, cast routinely as women who violate the natural bonds of family and kinship in order to inappropriately sell their reproductive and intimate labour to others.

Significantly, however, the term 'freelancer', which is now generally associated with contingent and own account professional work, has been appropriated by many migrant domestic workers as a category of self-identification. First, and most importantly, the term freelancing, as in its original usage, denotes that the freelancer has, quite literally in the case of many migrant domestic workers, escaped their employer's lordship and claimed de facto independence; more specifically, it refers to those who seek employment outside of the formal sponsorship system known as kafala. Second, appropriating the term freelancing asserts a professional status for themselves as domestic workers against their ascribed status as downwardly mobile maids, helpers or servants who 'do the dirty work'. Thirdly, I suggest that claim to independence complicates and troubles contemporary accounts of migrant domestic workers as victims of trafficking and forced labour.

Methodologically, the chapter draws on and brings together a growing body of research, including my own, on migrant domestic workers in Arab countries across the Middle East, some of which is discussed below (e.g. de Regt 2008, 2010; Fernandez and de Regt 2014;Frantz 2008, 2013; Gamburd 2000; Johnson 2010; Johnson and Wilcke 2015; Jureidini and Mourkabel 2004; Longva 1997; Mahdavi 2011; Mourkabel, 2009; Silvey 2004, 2006; Vligier 2012). The first part of the chapter reviews arguments put forward for categorising migrant domestic work in that region as a form of modern day slavery and/or system of trafficking. More specifically, I suggest that while there is some merit to 
describing migrant domestic work in Frantz's (2013) terms as a form of 'state sponsored bonded labour', the use of the term trafficking elides rather than illuminates complex processes through which agency is shaped and exercised in situations of constraint. Moreover, the implicit and explicit comparisons to the violent and forcible movement of people in the historical slave trade actually obscures and reinforces the key loci of power, state enforced employer control over people's labour and mobility. If analogies between contemporary migrants and older forms of enslavement are to be sought it is not in the system of transportation, but rather in the various and persistent actions people take against the very different systems of constraint that they face (O'Connell Davidson 2015).

The second part of the chapter describes how women who work as freelance migrant domestic workers challenge directly that state enforced control over their mobility, refiguring their ascribed status as either compliant workers or victims of trafficking by reorganizing social relations through an act of political prefiguration; that is through the defiant insistence on acting as if they were already free (Graeber 2009; 2014: 5). Describing the action of freelancers as a sort of direct action and political prefiguration might at first glance be seen as stretching the sociological definition of those terms. However, if, as others contend, the notion of prefiguration is not about people deciding in advance what counts or qualifies as an act of freedom or agreeing about what the aims of freedom should be, but rather simply about people reconstructing social relations by acting as if they were free, then it seems reasonable to suggest that freelancers are a sort of (non-violent) social movement (Maeckelbergh 2011; Graeber 2009). I refer to freelancers as a social movement despite the fact they rarely coalesce into formally organized collectives, though freelancers have taken a leading role in the recent founding of the first union of domestic workers in Lebanon (Kobiassy 2015). Just as importantly, freelancers are aware of, create and experience a sense of solidarity with other freelancers through discursive acts of identification, affirming and asserting that they are people who practice freedom, despite and because of the system of constraints they face. In that way freelancing is more than simply a form of resistance or weapon of the weak. Rather, as I demonstrate in this paper, freelancers are on the vanguard of those migrants who are seeking through their own actions to effect social change.

\section{Migrant domestic workers in the Middle East: a form of modern day slavery?}

Though not the earliest (Haddad 1999), the first systematic scholarly attempt at linking migrant domestic labour in the Middle East to modern day slavery was by Jureidini and Moukarbel (2004) who argued that the situation of Sri Lankan domestic workers in Lebanon 
approximated what, following Bales (1999), they describe as an example of modern day 'contract slavery' and 'debt bondage' characterized not by ownership but by control. Contract slavery is deemed to be a situation in which people voluntarily enter into a contractual relation of employment but where the contract is merely a ruse to cover over and sanction an employer's almost limitless control over employees. Jureidini and Moukarbel contend that is the case for many domestic workers in Lebanon whose contracts of employment neither adequately specified employer responsibilities nor were they backed up in law or in practice. Additionally, employees were sometimes unaware they had signed a contract or did not comprehend the content of the contract that they had signed because written in a language that they did not understand. In that situation migrant domestic workers entered a situation of employment ungoverned by employment legislation that effectively placed them at the mercy of employers and their beneficence.

Debt bondage is a situation where servitude is attached to the loan of money and where the length and nature of that servitude is indeterminate. Migrant domestic workers are nominally protected from debt bondage by a system that normally requires employers to pay the fees charged by recruitment agencies to find employees, oversee employment contracts, process paper work and arrange for travel. Jureidini and Moukarbel contend that on arrival migrant domestic employees were effectively placed in a situation of debt bondage by employers who held their employees responsible for the fees that they paid to recruitment agencies. Employers restricted their employee's movements by confiscating their passport and physically confining them to the home on the grounds that this was an important means of safeguarding their investment. They also note that despite the fact that employers are meant to pay recruitment agency fees, migrant domestic workers routinely contract debts to pay for agency fees in the home country.

Whether it is deemed contract slavery or debt bondage, Jureidini and Mourkarbel (2004: 597) suggest that migrant domestic workers in Lebanon face three conditions that are, 'sufficient to categorise their status as one of slavery', including abuse or threat of abuse and violence by employers or the employment agency; denial of freedom by employers and/or the state, including forced confinement, confiscation of passports and restrictions on changing employers; and exploitative working conditions with no formal employment rights and little legal recourse. What they significantly add to and revise in terms of Bales' original definition of modern day slavery is their insistence on the racialised nature of migrant domestic work and the forms of exploitation and abuse that characterise those relations. 
The situation that Jureidini and Mourkarbel describe for Sri Lankan migrants in Lebanon, especially those who are 'live in' domestic workers (the distinction between live in and freelancers is discussed further below) is one that has been widely reported and confirmed in the literature on migrant domestic workers in that region including scholarly accounts, and a number of important Human Rights Watch reports (Human Rights Watch 2008a, 2008b, 2010a, 2010b, 2011a, 2011b).

One important aspect that both HRW reports and anthropological work on migrant domestic labour highlight that was to a certain extent down played in Jureidini and Mourkarbel's original account is the kafala system of sponsorship put in place by countries throughout the region as a way to transfer responsibilities for the management of migrants onto their populace. The role of the kafala in relation to expatriate workers, including domestic workers, was first systematically described in the scholarly literature by Longva (1997) in her seminal study of transnational migrants in Kuwait, where she outlined among other things transformations in and differences between former relationships of indentured labour and contemporary relations between migrant workers and their sponsors. More recently, Elisabeth Frantz (2013) building on those and other insights about kafala (Gardner 2010) extends and refines the initial arguments made by Juriedini and Mourkabel (2004) suggesting that migrant domestic work in that world region may best be conceived as a form of state sponsored bonded labour.

Frantz suggests that bonded labour is the best way to characterise the situation of migrant domestic workers who are effectively bound to their employers in multiple ways including indebtedness and the kafala system for a specified period of time at the end of which they are expected to return home rather than granted settlement rights. The key point for Frantz is that this form of unfree labour is neither simply the result of states turning a blind eye to practices hidden from sight nor of failing to extend employment protection or preventing people from being enslaved, but rather is about the way the system is, 'facilitated and enforced by the state and plays a fundamental role in the economy' (2013:1073, see also Johnson and Wilke 2015). Crucially Frantz suggests that it is not just receiving states but also sending states who facilitate this form of unfree labour. The latter do so both by actively 'brokering' their citizens as migrant labour (Rodriguez 2010) and by enforcing conditions of bonded labour in destination countries through complicity and compliance by, for example, reporting employees who have escaped abusive employers.

An important corollary of Frantz' argument is that this system of unfree labour depends on a regular, if selectively regulated, system of internationally mobile labour. It is 
precisely for that reason that Frantz suggests that recent and growing emphasis on 'trafficking' and other forms of irregular migration are misguided. In what follows I examine in more detail two recent contrasting arguments about the applicability of the term 'trafficking' to migrant domestic workers in this situation.

Trafficking is, following UN conventions and the Palermo Protocol, sometimes used to describe the situation of migrant domestic workers who are deemed to have been recruited through duplicitous means and hence transported without their consent for the purposes of exploitation. One of the strongest scholarly statements in support of that view is by Vligier (2012: 182, 185) who, writing about Saudi Arabia and the Emirates, suggests that because forced labour and practices similar to slavery are 'general market conditions' and because migrant domestic workers are 'misinformed or deceived about the most important working conditions' then many migrant domestic workers ought properly to be regarded as the victims of trafficking.

Drawing on survey questionnaire research with Indonesian and Filipino migrants prior to departure, Vlieger reports that half of her Filipino respondents said that they were told they would not, or probably would not, be allowed to leave the home, while the other half were either not told anything or were told that they would be able to leave. The majority of Indonesian respondents reported that they were told that they would not be able to leave their employers' households, but Vlieger surmises based on interviews with recruitment agents that their knowledge of that was likely based on what was reported by other migrant domestic workers rather than disclosure by recruiters. Vlieger suggests likewise that migrants are misinformed about other aspects of employment including salary, rest periods and days off.

The question of deception in relation to securing migrants' consent is crucial here because despite the evocative language of trafficking, this is not a case of people being physically coerced and transported for labour: rather, in quite the opposite manner, this is a system that requires migrants in one way or another to choose to migrate and to invest time, resources and personal effort and energy to become a migrant to undertake employment abroad. Vligier's argument that migrant domestic workers are the victims of trafficking is premised on the claim that migrant domestic workers are systematically misled by duplicitous recruiters and employment agents about the exploitative conditions of employment that they will face. Juriedini (2010) by contrast contends that designating this as trafficking by deception hinges both on establishing deliberate acts of deception on the part of individual recruiters, employment agencies and employers, etc., and establishing that a particular individual was a victim of their deception. As Juriedini makes clear, the process through 
which migrant domestic workers are produced, recruited and transported is complex and not infrequently involves a range of both state and non-state actors (see also Frantz 2013, Lindquist 2012). In that situation, it is virtually impossible to distil out and identify who the individual traffickers are that might be held responsible since it is also the case that while some migrant domestic workers do experience exploitative working conditions amounting to forced labour and slavery-like practices, others do not. Vlieger (2012:189) claims that the difficulty of assigning or apportioning individual culpability and intent is not salient when, 'one switches the focus from individual cases towards the fact that exploitation of domestic workers in Saudi Arabia and the Emirates is the rule, not the exception.'

There is general agreement that the system of transnational migrant domestic labour in the Middle East is a particularly exploitative form of unfree labour. The problems with labelling that system 'trafficking' are several and extend beyond the question of whether or not it is possible to establish individual culpability, to whether internationally agreed definitions of trafficking may appropriately in their own terms be used to designate the entire system of migrant domestic labour from recruitment in country of origin to deployment in host country. As descriptive categories, trafficking, contract slavery and debt bondage are all limited in so far as they hone in one aspect or set of agents for targeted interventions, be it duplicitous recruitment practices, the inadequacy of employment contract or the ways that employers hold employees responsible for the recruitment fees incurred by employers. The notion of state sponsored bonded labour used by Frantz (2013) comes closest to describing the system of unfree labour as a whole. It doing so it foregrounds both sending and receiving states involvement and investment in producing that system and highlights the need for state led reforms that minimally include the enactment of enforceable employment law for domestic workers and amendment of the kafala system of sponsorship to remove employer control over their employees' movement and residential status.

Further, as Vligier and Jureidini's discussion illustrates, the discourse of trafficking in particular tends to reduce the issue to a question of choice versus compulsion or deception at the point of entry and movement. As others have suggested, that focus on the process of arrival may result in restricting further people's freedom of movement internationally rather than addressing the basis for people's exploitation in work situations in the countries in which they live and labour (Anderson and O'Connell Davidson 2004; Andrijasevic 2007; O'Connell Davidson 2010). The discursive structure and legal frameworks of trafficking effectively turn what is a complex process and set of relationships into a simple binary of people either voluntarily undertaking labour migration or becoming victims of trafficking subject to 
exploitation and forced labour. Following Brace (2013) what we see again here in respect of women who are migrant domestic workers are certain gendered presumptions about different sorts of people's capacity to act based on liberal notions of individual self-possession, including the possession of all the facts, that underpins economistic and legalistic models of rational social actors.

\subsection{Conceptualizing migrant domestic worker agency beyond 'compulsion by necessity'.}

Just as some scholars have argued that 'contemporary labour relations often cannot in any useful sense be positioned on one side or other of a clear dividing line between "free" and "unfree' labour" (Barrientos, Kothari and Phillips 2013: 1038), so too the line between free and involuntary movement is rarely as neat as the discourse of trafficking conceives it. One way of addressing the issue of agency that begins to move beyond the simplistic binary of forced and voluntary movement and labour is to conceptualize people's choice as 'compulsion by necessity' (O’Neill 2011: 16, cited in Fernandez 2014: 54). Fernandez (2014) describes how in straightened economic times migration has become an important household diversification strategy within which Ethiopian women elect to become migrant domestic workers. The reference to the household is indicative also of the way that agency is relationally constituted in ways that troubles notions of an autonomous liberal self (Mahdavi 2014), whether those relations are conceived of as familial, households, inter-generational or sibling set kinship obligations (Aguilar 2013) or, more broadly, in terms of membership in the imagined national community (Anderson 2006).

Existing scholarship on the gendering of Filipino migrant domestic labour as the new hero has shown, for example, how successive governments in the Philippines have mobilized a discourse that links and transforms the needs and aspirations of individual migrants into those of the nation as a whole in ways that exert a disciplining power on them (Parreñas 2001; Rodriguez 2002). In that way, as Rodriguez (2010) contends, it is impossible to understand the situation of migrants who choose to work abroad without first comprehending the production of workers in and by the state in the home country.

Though the notion of compulsion by necessity combined with a more nuanced understanding of the relations involved in producing and enabling migrant 'agency' complicates considerably stories about trafficking, there are two further points that need to be made here. The first is that in the case of the Philippines and in some other migrant sending countries also, migrants are rarely from the poorest and most impoverished groups of people and migrant domestic work is as often about aspiration as it is necessity. The second point is 
that just as a focus on the duplicitous actions of recruiters reduces women to victims of trafficking, so too it is possible to overemphasise the work and agency of others, be that the sending state, kinship group or household, in producing women who are able and willing to migrate. Women's choice to migrate may be part of a household's or wider kinship group's economic strategy, but it is noteworthy that electing to become a migrant is in fact often initiated by women against the wishes or despite the initial reluctance of husbands, fathers and brothers. In a pre-migration study of legal migrant workers in 2004 conducted by the Scalabrini Centre for Migration in the Philippines, that included both survey of 990 migrants, mainly women, as well as focus group discussions (FGD), the investigators concluded, 'that migrants are the ones who decide to migrate. The FGDs, in particular, highlighted that migrants, including women migrants, would even defy their spouses' or parents' wishes because they were convinced that working abroad was the only way to improve their family situation' (Asis 2005: 23).

Undertaking domestic work abroad evidently lacks the status that women who secure professional work abroad may obtain and that at least partially ameliorates objections based on gender norms about absent mothers. Domestic work by contrast is not only regarded as a lowly occupation and the economic rewards and social mobility that migrant domestic work potentially confers is often accompanied by downward social status. Just as significantly it also is perceived to entail exiting, at least temporarily, their ascribed positions of daughter, sister, wife and/or mother and converting their nominally gifted labour into a commoditized relation in which they are expected to perform or undertake some of the same intimate labours for strangers in exchange for a wage. That particular configuration of gendered and classed ideologies positions women who are migrant domestic workers simultaneously as both new heroes and in Brace's (2013) terms, 'freelance hustlers'. Women continually negotiate that transgressive, victim and new hero position within family and household, both prior and subsequent to departure across the course of their migrant careers (Gibson, Law and McKay 2001).

Anju Paul (2015) describes in more detail the household and family level negotiation processes that Filipino independent women labour migrants undertake in order to secure the necessary financial backing and emotional support needed to undertake mobility. Filipino women as elsewhere are more likely than men to encounter resistance to their independent migration. They are nonetheless able to secure familial support if not wholehearted endorsement by casting migration as fulfilment rather than transgression of gender appropriate roles as devoted wife, dutiful daughters and caring mother. Her conclusion is 
that, while 'women migrants break gender barriers when it comes to their independent labor migration, they do so by “doing," rather than "undoing," gender' (2015:1).

Gender may not be 'undone' entirely, but it is important not to underestimate what those women accomplish by redefining spatially and conceptually normative practices of femininity and masculinity: left behind men with migrant wives can and do redefine masculinity and husbandry at least partially (Pingol 2001) and women are able to redefine and reformulate femininity in and through migration (Johnson 1998). Moreover, while women may claim in response to formal interview questions that their primary motivation in undertaking migrant domestic work abroad is to meet perceived material needs, invest in new homes or businesses, enhance a sibling or child's life chances, what anthropological work drawing on informal ethnographic encounters demonstrates is that women cite many reasons for migration that include among other things, adventure, opportunity for travel and to experience new places, religious pilgrimage, leaving abusive husbands and failed marriages, beginning new relationships and acquisition of new skills. The journeys that women embark on and undertake may also be conceived of in different ways and frequently evolve en route. For some women, initial and temporary sojourns as domestic worker in Saudi Arabia or Hong Kong may be imagined as a 'stepwise' process leading on eventually to opportunities for immigration and permanent settlement abroad in places like the USA or Canada (Paul 2011). For others, what may have begun as a simple temporary journey may either become one part of a longer journey going on or on (Liebelt 2008) without any fixed or final destination, or may lead to feelings of attachment and a desire for settlement in new places even those where settlement and permanent residency is impossible, as is the case with countries throughout the Middle East region (Elyas and Johnson 2014).

In sum, the decision to become a migrant domestic worker may be a sort of compulsion by necessity and in conditions where the person choosing to migrate is not given all the facts and/or may be subject to deliberate duplicity. In many other cases, women choose to become migrants and undertake domestic work not because necessity demands it but because it is deemed to be the best available option to pursue what may in fact be a variety of contradictory claims and aspirations. In doing so, as the results of Vlieger's own survey suggests, many if not the majority, are aware of the different sorts of conditions that they might potentially face. It is also entirely plausible and hardly surprising that, as Vlieger suggests, most people's information about the actual conditions of employment come not from recruiters but from fellow migrants. To be sure, as Gardner (2012) contends, stories told by migrant returnees will always be selective and may down play personal exploitation in 
order to accentuate personal success in ways that can create misleading impressions of life and work in the Gulf. It is that prospect of success that many people cling on to at the same time that they are aware that securing an employer who is fair and reasonable, if not generous, is always a matter of luck, rather than a legally guaranteed certainty. That is the gamble that most migrants that I have encountered in the Philippines as in Saudi Arabia were willing to take. Moreover, as I describe below, just as for some women the act of departure required negotiating the reluctance and sometimes resistance on the part of other household and family members to secure their exit, so too there are those who do not rely solely on fate or the decency of employers but on their own direct action to ensure that even if they do end up with an abusive or exploitative employer, they will not remain there: exit always remains a possibility despite the systems of symbolic violence and structural constraints that seek to keep them in their place.

\section{Freelancing}

Recent writing and research on migrant domestic workers in the Middle East frequently distinguishes between contract and freelance workers. As summarised by Fernandez and de Regt (2014: 9-13), contract workers enter into formal employment contracts with employers through employment agencies that nominally specify salaries, hours of employment, duration and other rights. These contracts, first signed in the sending country, are often not legally binding and are frequently altered in the destination country. Contract workers are also subject to the kafala sponsorship system in which an employee's residency permit is tied to their employers who act also as their visa sponsor. They can neither seek alternative employment nor leave the country without the consent of their employer, who often confiscates their passport. Contract workers normally live with their employers as a condition of employment and residency: their mobility is thus constrained legally, physically and socially.

Freelancers are workers who exit their formal contract, their employer's home and, as a consequence, their conditions of stay to become irregular residents who enter informal contractual arrangements with a new employer and, if possible, live outside of the new employer's home. In some cases, freelancers may pay their original employer so they can live outside of the latter's home and work for someone else while remaining tied nominally to their visa sponsor who is named on their residency papers. The practice is not legal, though it is reportedly wide spread. Freelancers may work for more than one household or in other part time jobs. Just as there is some variation in the specificities of contract work under the 
kafala system in different countries in the Middle East, so too there is some variation in the organization of freelance work, the conditions that lead to migrant domestic workers' exit from their original employer and the situations that they encounter on leaving. Nonetheless, there are a number of general points about freelancing that are widely reported from across the region.

First, many women who exited formal contracts often did so to escape acute forms of exploitation and abuse (Johnson and Wilcke 2015; Madhavi 2011), whether that is long term withholding of salaries, physical coercion or sexual violence. They subsequently became "freelancers" who sought better living and working conditions. However, there is also evidence to suggest that other women see formal contracts as initial staging posts to seek work as freelancers, or whose initial entry into the host country as irregular migrant requires and facilitates direct entry into freelance contracting (Fernandez 2014: 69; de Regt 2008). Second, it is important to clarify that for those individuals in existing formal contracts the threat of going 'freelance' does not appear to be a bargaining chip in negotiations between domestic workers and their regular employers/sponsors. Rather, it is only after one has left that regular employment and become a 'freelancer' that opportunities arise to seek out and bargain for an improved situation. As reported widely from across the region, and elsewhere, women working as 'freelancers' and who lived outside of their employers homes were likely to report better pay and working conditions and greater autonomy than those employed on a regular contractual basis (Fernandez and de Regt 2014; Frantz 2008).

Third, while 'freelancers' generally enjoy better working conditions, leaving an employer without their consent or complicity is risky for a variety of reasons. The women are likely to be reported to the authorities and if apprehended, will be treated as in violation of residency laws, and possibly even as criminals (Fernandez and de Regt 2014; Strobl 2009). They are often forced to leave without any formal residency papers or their passports, which remain in the possession of their employer. In that way, as Lan (2007) observed about the situation of undocumented migrant domestic workers in Taiwan, the trade-off is sometimes perceived to be between 'legal servitude' and a form of 'free illegality'. Moreover, freelancing is not just an unintended consequence of the state sponsorship system. Rather the state is also part of, and profits from, the production of this form of irregular labour. As Johnson and Wilcke (2015: 146) suggest elsewhere,

In the regular system of contract employment and state sponsorship, the gendered notion of privacy functions to protect a system that is heavily slanted in favour of the employer. In the system of irregular migrant work that is its corollary, privacy is also 
the basis on which the state can conveniently turn a blind eye to employer violations of the state sponsorship system, while using a system of fines to heavily penalize those migrants whose residential status is deemed to be irregular. That selective vision paradoxically provides migrant domestic workers who have left their original employer some small opening to negotiate better pay and working conditions outside of the formal sponsorship system, but it does so at a price.

\section{Freelancing as political prefiguration}

Having outlined some of the contours of freelancing among migrant domestic workers in the Middle East I set out the reasons for suggesting that freelancing might be deemed an act of political prefiguration. It is important to be clear first of all about the symbolic and subjective significance of migrant domestic worker's use of the term 'freelancing' and 'freelancer' as a label of self-identification. As I describe elsewhere, being able to leave an employer and become a freelancer is partly enabled by and dependent on the social networks of kin and compatriots they, and others, are able to access and mobilize on their behalf (Johnson 2010). One of the social costs of that mobilization, especially when it depends on compatriots who occupy a higher class position, is the stigma of being labelled a runaway or escapee.

Filipinos, for example, commonly refer to migrant domestic workers who are living irregularly as takas, a word that describes someone who has taken flight to escape confinement and/or an abusive employer. Identifying someone as takas conveys pity for a victim of difficult circumstances whose only option is to take flight and run. One Filipino woman who routinely employed irregular Filipino workers in her beauty parlour described her business as 'an orphanage for takas.' (Johnson and Wilcke 2015: 151). Especially as applied to domestic workers, takas may also suggest some moral failing on the part of the person so identified, and in the case of women is linked either to an assumption that they have been sexually violated and/or to judgment about their presumed sexual promiscuity. Identifying as a freelancer is a conscious refusal of the label takas and other status categories variously ascribed to, and occupied by, domestic workers - be it the putatively good and compliant servant, absconder, criminal, victim, or runaway charity case and conveys the capacity to take positive action the aim or goal of which is more than simply escape or flight. In a situation where migrant domestic work generally is associated with downward social mobility in terms of occupational status, identifying oneself as a 'freelancer' is also a way of affirming the value, worth and skill of the work that one does in domestic employment. 
I contend, however, that the significance of freelancing, as both a relation of employment and a category of identification, extends beyond the opportunities and subjective meanings it carries for particular people. More specifically I argue that freelancing transforms a workers' exit from their employer from an act of resistance and weapon of the weak (Scott 1985) into an act of political prefiguration. It is important to be clear here that rather than try to specify sociologically the precise characteristics or features that count or qualify in order to designate a movement or action 'prefigurative' (see Yates 2015), I take a more minimalist approach that understands prefigurative politics as any form of direct action that simultaneously challenges existing structures and that creates alternatives in the present (Maeckelbergh 2011; Graeber 2009) without any necessary collective agreement on what those alternatives are, or should be, or on the best ways to achieve them. In that way prefigurative politics clearly includes aspects of resistance, but extends both beyond hidden transcripts and overt challenges and acts of insubordination to secure in some way, however partial and temporary, the reorganization of relations. On that basis, I think we can reasonably suggest that freelancing is a kind of direct action and form of political prefiguration for the following reasons.

First, as Fernandez (2014) notes, writing about Ethiopian migrant domestic workers in Lebanon and Kuwait, while governments and employers' routinely cite absconding employees as justification for constricting mobility and in the latter case confiscating passports, the threat of exit continues to exist despite, and precisely because of, the constraints in place to prevent it. The possibility of exit, moreover, 'generates a fundamental instability in the relationship' and makes evident the 'structural contradiction that has transformative potential' (Fernandez 2014: 69). As Johnson and Wilcke (2015) writing about Saudi Arabia suggest, freelancing makes explicit the temporally and materially contingent basis of women's intimate labour in a situation where there is otherwise a presumption of ownership and control over their bodies and the work that they do. It also reveals the gaps between the state-sanctioned cultural fictions that publically legitimate and sustain the system of sponsorship and the more variable social practices of employees and employers. Regional governments routinely claim that cultural norms underpin the legal requirement for employees to live in, be part of, and be restricted to the family home in which they labour. Freelancers who are more likely to 'live out' than 'live in' demonstrate that employers will accept alternative living and working arrangements that apparently transgress those state sanctioned conventions. 
Second, and following on from that, exit is not just escape from a situation of abuse and constraint but movement to, and at least the partial reorganization of, the relationship between employee and employer in the relationship of domestic labour. That scholars writing about migrant domestic work in the Middle East now describe that as being organized in one of two major ways, i.e. as either contract or freelance (Fernandez and de Regt, 2014, see above), is a testament to thefact that migrant domestic workers have through practice created an alternative set of social arrangements. As Vlieger (2011: 108) observes, 'while "freelancers" contrast themselves to those migrants who are nominally "contract workers", $[\ldots]$ it is the freelancer whose labor relation [based on verbal agreement] is more contractual, whereas the position of the live-ins is more status-based and patriarchal'.

Third, migrant domestic workers have not only creatively appropriated the term 'freelancing' to nominate this alternative form of relationship but also are widely reported to be involved in circulating the idea of freelancing as an alternative form of working among fellow migrants employed in domestic workers in host society and among prospective migrants in home country. They may also assist fellow domestic workers to leave abusive employers and provide contacts to enable them to enter into freelance working arrangements. Amrita Pande (2014) writing about migrant domestic workers in Lebanon, for example, notes that women working as freelancers frequently gather on Sundays and form 'informal' support groups. The members of the support groups pay dues, appoint committees and provide financial assistance, as well as advice and contacts for new runaways seeking freelance work.

Also, in Lebanon in the early part of 2015, a group of women, led by freelancers, established the first migrant domestic workers union in the region (Kobaissy 2015). Kobaissy (2015) provides the earliest systematic account of the formation of that union and shows how the emergence of the union grows out of, and to some extent brings together, prior sites of migrant advocacy and solidarity, including religious groups and national communities on the one hand, and NGOs in conjunction with ILO and a national federation of labour organizations, FENASOL, on the other. Significantly she describes how many of the most active militants in the union were freelancers drawn from across different national communities. For Kobaissy what made freelancers ideal leaders in that movement was the relative duration of their stay in Lebanon (between 7 and30 years) and their greater mobility than live in domestic workers, coupled with their wealth of experience in assisting fellow migrant domestic workers in Lebanon, and for some, previous experience of labour activism in their country of origin. Kobiassy likewise suggests that the formation of the union may be seen as evidence that domestic workers have opened a new political front beyond that of the 
everyday forms of resistance. I agree and would only add here that the opening of that front commenced the moment that a migrant domestic worker first exited the home of her employer to become a freelancer, and it is that experience of taking direct action that positions freelancers as ideal leaders of this new union.

\section{Conclusion: fashioning futures beyond kafala}

Promises to reform the kafala system have been made repeatedly by Arab countries in the Middle East. Confronted by increasing media attention to the precarious situation of workers preparing for FIFA's troubled World Cup, the Qatari government promised to bring forward reforms in $2015 .^{2}$ What exactly those reforms will be and whether they will ever be delivered is an open question there and in the rest of the region. One of the key stumbling blocks that reportedly remain is reluctance to remove employer control over their domestic employees' movements since more than any other element of the potential reform, this is deemed by regional governments to work against both conventional gender norms and the perceived interest of their citizens who might otherwise have to contend with employees free to take their labour elsewhere and subsequently drive up wages (see Johnson and Wilcke 2015). In the meantime, there remain women who continue to act as if they were free despite and precisely because of the system of constraints that they face, acts of individual and collective civil disobedience and political prefiguration that, more than international media coverage or human rights reports, make the argument for freedom of movement in a courageously concrete manner.

There are four final points that I wish to make in conclusion. First, while the media increasingly latches on to stories about kafala as an exotic Arab system of modern day slavery, it is important to recall that a system that ties migrant domestic workers conditions of stay to their employers and restricts their freedom of movement it is found in a variety of more and less extreme forms across the world, including in Britain (see e.g. Anderson 2000). Second, the discourse of modern day slavery and trafficking picked up in the media casts migrants, especially migrant domestic workers, in the role of victims. They appear as women who have been forced, by necessity or duplicity, to leave their homeland, cultures and families to inappropriately, if tragically, (s)eek out an existence elsewhere (Brace, 2013). Such a view not only obscures migrant agency and capacities to act but also just as

\footnotetext{
${ }^{2}$ See e.g, http://www.aljazeera.com/news/2015/09/uae-announces-labour-reforms-protect-foreign-workers150929143336000.html (accessed 7 April, 2016) and https://www.hrw.org/news/2015/11/15/saudi-arabiasteps-toward-migrant-workers-rights (accessed 7 April, 2016).
} 
importantly elides the fact that it is migrant sending states, as much if not more than migrants themselves, whose participation in facilitating forms of bonded labour may appropriately be deemed 'compulsion by necessity'. That is to say, dependence on migrant remittances by some governments in the global south is at least indirectly the product of external demands imposed by indebtedness and subordination to the IMF (Enloe 2000).

Third, international organizations and transnational migrant alliances have often intervened to offer support and succour for migrant domestic workers. They have also been instrumental in exerting pressure on receiving states to reform the kafala system and on sending countries to ensure that the remittances they rely on (to meet their external obligations) are not at the expense of those who are both 'inflexible citizens' and 'flexible noncitizens' (Constable 2009; Mahdavi 2014). However, the discourse of slavery that is sometimes mobilized by the former especially to press for that change systematically ignores and misrepresents forms of direct action taken by the latter to challenge daily the system of constraints that they face: that is to say, the dominant image is of women who, having through their own efforts escaped abuse and exploitation, sit passively awaiting their salvation and repatriation. Such a view replays European abolitionist accounts of emancipation in the past that likewise systematically underplayed the actions taken by the enslaved to liberate themselves. It also creates a situation where proposals brought forward to reform the existing sponsorship system are unlikely to enshrine or guarantee as legal rights the hard won benefits that domestic workers achieve currently through exit from formal employers and entry into informal contracts of employment as freelancers. Freelancers, in other words, have set the bar by which any formal reorganization of the sponsorship system and extension of employment legislation ought to be measured.

Finally, it is important to note that while the actions of freelancers are directed against the structural violence that they face and combat on a daily basis, this is not, as indicated at the outset, part of a common political project or agreed upon programmatic framework. For some, including those in the nascent union in Lebanon documented by Kobiassy (2015) who have previous experience of workers' rights advocacy in their home countries, it may be tied to a broader anti-global capitalist discourse or identifiably 'progressive' politics (see also Constable 2009 on migrant domestic worker activist in Hong Kong). For others, becoming a freelancer is primarily about asserting their liberty to participate and sell their labour in more favourable circumstances and reorganizing social relations in such a way that compels recognition by states and employers that they are more than disposable people. 


\section{References}

Aguilar, F. (2013), 'Brother's keeper? Siblingship, overseas migration, and centripetal ethnography in a Philippine village', Ethnography, 14(3): 346-368. DOI $10.1177 / 1466138113491674$

Anderson, B. (2000), Doing the dirty work?: The global politics of domestic labour (London, Palgrave Macmillan).

Anderson, B. (2006), Imagined communities: Reflections on the origin and spread of nationalism (London, Verso Books).

Anderson, B., \& O’Connell Davidson, J. (2004), Trafficking-a Demand Led Problem? (Sweden, Save the Children).

Andrijasevic, R. (2007), 'Beautiful Dead Bodies: Gender, Migration And Representation In Anti-trafficking Campaigns', Feminist Review 86: 24-44. DOI 10.1057/palgrave.fr.9400355

Asis, M. B. (2005), Preparing to Work Abroad: Filipino Migrants' experiences prior to departure (Manila: Scalabrini Migration Centre).

Bales, K. (1999), Disposable People: New Slavery in the Global Economy (Berkeley, University of California Press).

Barrientos, S., Kothari, U. and Phillips, N. (2013), 'Dynamics of Unfree Labour in the Contemporary Global Economy', The Journal of Development Studies 49(8): 1037-1041. DOI 10.1080/00220388.2013.780043

Brace, L. (2002), 'The tragedy of the freelance hustler: Hegel, gender and civil society', Contemporary Political Theory, 1(3), 329-347.

Brace, L. (2010), 'Improving the Inside: Gender, Property and the 18th-Century Self', The British Journal of Politics \& International Relations, 12(1): 111-125. 
Brace, L. (2013), Borders of emptiness: gender, migration and belonging. Citizenship Studies, 17(6-7), 873-885. DOI 10.1080/13621025.2013.834143

Constable, N. (2009), 'Migrant workers and the many states of protest in Hong Kong', Critical Asian Studies, 41(1): 143-164. DOI 10.1080/14672710802631202

de Regt, M. (2008), 'High in the Hierarchy, Rich in Diversity: Asian Domestic Workers, Their Networks, and Employers' Preferences in Yemen', Critical Asian Studies, 40(4):587608. DOI 10.1080/14672710802505307

de Regt, M. (2010), 'Ways to Come, Ways to Leave: Gender, Il/legality and Mobility Among Ethiopian Domestic Workers in Yemen', Gender and Society, 24(2): 237-60. DOI DOI 10.1177/0891243209360358

Elyas, N. \& Johnson, M. (2014), 'Caring for the future in the kingdom of Saudi Arabia: Saudi and Filipino women making homes in a world of movement', in B. Fernandez and M. de Regt (eds), Migrant Domestic Workers in the Middle East: the Home and the World. (London, Palgrave McMillan), 141-164.

Enloe, C. (2000), “'Just Like One of the Family”: Domestic Servants in World Politics', in M. Zimmerman, J. Litt \& C. Bose (eds), Global Dimensions of Gender and Care Work. (Palo Alto, Stanford University Press), 118 - 122.

Fernandez, B. (2014), 'Degrees of (Un)Freedom: The Exercise of Agency by Ethiopian Migrant Domestic Workers in Kuwait and Lebanon', in B. Fernandez and M. de Regt (eds), Migrant Domestic Workers in the Middle East: The Home and the World (New York, Palgrave Macmillan), 51-74.

Fernandez, B., \& De Regt, M. (2014), 'Making a Home in the World: Migrant Domestic Workers in the Middle East' in B. Fernandez and M. de Regt (eds), Migrant Domestic Workers in the Middle East: The Home and the World (New York, Palgrave Macmillan), 126. 
Frantz, E. (2008), 'Of Maids and Madams: Sri Lankan Domestic Workers and their Employers in Jordan', Critical Asian Studies, 40(4):609-38. DOI $10.1080 / 14672710802505323$

Frantz, E. (2013), 'Jordan's Unfree Workforce: State-Sponsored Bonded Labour in the Arab Region', The Journal of Development Studies, 49(8): 1072-1087. DOI $10.1080 / 00220388.2013 .780042$

Gamburd, M. (2000), The Kitchen Spoon's Handle: Transnationalism and Sri Lanka's Migrant Housemaids (Ithaca, NY, Cornell University Press).

Gardner, A. (2010), 'Engulfed: Indian Guest Workers, Bahraini Citizens and the Structural Violence of the Kafala System', in N. de Genova and N. Peutz (eds), The Deportation Regime: Sovereignty, Space, and Freedom of Movement (Durham, NC, Duke University Press), 305-349.

Gardner, A. (2012), 'Why Do They Keep Coming? Labor Migrants in the Gulf States', in M. Kamrava and Z. Babar (eds), Migrant Labour in the Persian Gulf, (New York, Columbia University Press), 41 - 58.

Gibson, K., Law, L., \& McKay, D. (2001), 'Beyond heroes and victims: Filipina contract migrants, economic activism and class transformations', International Feminist Journal of Politics, 3(3), 365-386. DOI 10.1080/14616740110078185

Graeber, D. (2009), Direct action: An ethnography (London, AK press).

Graeber, D. (2014), 'Anthropology and the rise of the professional-managerial class', HAU: Journal of Ethnographic Theory, 4(3), 73-88. DOI 10.14318/hau4.3.007

Haddad, R. (1999), 'A modern-day “slave trade”: Sri Lankan workers in Lebanon', Middle East Report 211:39-41.

Human Rights Watch. (2008a). "As If I Am Not Human”: Abuses Against Asian Domestic Workers in Saudi Arabia (New York, Human Rights Watch). 
Human Rights Watch. (2008b), Perpetual Minors: Human Rights Abuses Stemming from Male Guardianship and Sex Segregation in Saudi Arabia (New York, Human Rights Watch).

Human Rights Watch. (2010a.) Without Protection: How the Lebanese Justice System Fails Migrant Domestic Workers (New York, Human Rights Watch).

Human Rights Watch. (2010b), Walls at Every Turn: Abuse of Migrant Domestic Workers Through Kuwait's Sponsorship System (New York, Human Rights Watch).

Human Rights Watch. (2011a), Saudi Arabia: Country Report (New York, Human Rights Watch).

Human Rights Watch. (2011b), Domestic Plight: How Jordanian Laws, Officials, Employers, and Recruiters Fail Abused Migrant Domestic Workers (New York, Human Rights Watch).

Johnson, M. (1998), ‘At Home and Abroad: Inalienable Wealth, Personal Consumption and Formulations of Femininity in the Southern Philippines', in D. Miller, (ed.), Material Cultures: Why Some Things Matter (Chicago, University of Chicago Press), 215-238.

Johnson, M. (2010), 'Diasporic Dreams, Middle Class Moralities and Migrant Domestic Workers among Muslim Filipinos in Saudi Arabia', The Asia Pacific Journal of Anthropology, 11(3-4): 428-448.

Johnson, M \& Wilcke, C. (2015), 'Caged in and breaking loose: intimate labor, the state and migrant domestic workers in Saudi Arabia and other Arab countries', in S. Friedman and P. Mahdavia (eds), Migrant Encounters: Intimate Labor, the State and Mobility across Asia (Philadelphia, University of Pennsylvania Press), 135-159.

Jureidini, R. (2010), 'Trafficking and Contract Migrant Workers in the Middle East', International Migration, 48 (4), 142-63. DOI 10.1111/j.1468-2435.2010.00614.X 
Jureidini, R. \& Moukarbel, N. (2004), 'Female Sri Lankan domestic workers in Lebanon: a case of “contract slavery"?', Journal of Ethnic and Migration Studies, 30(4), 581-607. DOI $10.1080 / 13691830410001699478$

Kobaissy, F. (2015), Organizing the Unorganized: Migrant Domestic Workers Labor Union Organizing in Lebanon, Unpublished MA Thesis, (Cairo, American University Cairo).

Lan, P.-C. (2007), 'Legal Servitude and Free Illegality: Migrant “Guest”'Workers in Taiwan', in R. S. Parreñas and L. C. D. Siu (eds), Asian Diasporas: New Formations, New Conceptions (Stanford, Stanford University Press), 253-277.

Liebelt, C. (2008), 'On sentimental Orientalists, Christian Zionists, and working class cosmopolitans: Filipina domestic workers' journeys to Israel and beyond', Critical Asian Studies, 40(4): 567-585.

Lindquist, J. (2012), 'The elementary school teacher, the thug and his grandmother: informal brokers and transnational migration from Indonesia,' Pacific Affairs, 85(1), 69-89. DOI http://dx.doi.org/10.5509/201285169

Longva, A.N. (1997), Walls Built on Sand: Migration, Exclusion, and Society in Kuwait (Boulder, CO, Westview Press).

Mahdavi, P. (2011), Gridlock: Labor, Migration and Human Trafficking in Dubai (Stanford, CA, Stanford University Press).

Madhavi, P. (2014), 'Immobilized Migrancy: Inflexible Citizenship and Flexible Practices Among Migrants in the Gulf', in B. Fernandez and M. de Regt (eds), Migrant Domestic Workers in the Middle East: The Home and the World (New York, Palgrave Macmillan), 7594.

Maeckelbergh, M. (2011), Doing is believing: Prefiguration as strategic practice in the alterglobalization movement. Social Movement Studies, 10(01), 1-20. DOI $10.1080 / 14742837.2011 .545223$ 
Moukarbel, N. (2009), Sri Lankan Housemaids in Lebanon: A Case of 'Symbolic Violence' and 'Everyday Forms of Resistance' (Amsterdam, Amsterdam University Press).

O’Connell Davidson, J. (2010), 'New slavery, old binaries: human trafficking and the borders of “freedom"”, Global networks, 10(2), 244-261. DOI 10.1111/j.1471-0374.2010.00284.x

O’Connell Davidson, Julia. (2015), Rights talk, wrong comparison: trafficking and transatlantic slavery. (Beyond Trafficking and Slavery, Open Democracy), <Accessed 1 July, 2015> https://www.opendemocracy.net/beyondslavery/julia-o\%27 connell-davidson/rightstalk-wrong-comparison-trafficking-and-transatlantic-sl

O'Neill, J. (2011), The varieties of unfreedom (Manchester Papers in Political Economy, no. 4/11, Manchester, University of Manchester).

Osnowitz, D. (2010), Freelancing Expertise: Contract Professionals in the New Economy (Ithaca, New York, ILR Press, an imprint of Cornell University Press).

Pande, A. (2014), 'Forging Intimate and Work Ties: Migrant Domestic Workers Resist', in B. Fernandez and M. de Regt (eds), Migrant Domestic Workers in the Middle East: The Home and the World (New York, Palgrave Macmillan), 27-50.

Parreñas, R. (2001), 'Transgressing the Nation-State: The Partial Citizenship and "Imagined (Global) Community" of Migrant Filipina Domestic Workers', Signs: Journal of Women in Culture and Society, 26(4): 1129-1154. DOI 10.1086/495650

Paul, A. (2011), 'Stepwise International Migration: A Multistage Migration Pattern for the Aspiring Migrant', American Journal of Sociology, 116(6): 1842-86. DOI 10.1086/659641

Paul, A. (2015), 'Negotiating Migration, Performing Gender', Social Forces, 94 (1): 271-293. DOI 10.1093/sf/sov049

Pingol, A. (2001), Remaking Masculinities: Identity, Power, and Gender Dynamics in Families with Migrant Wives and Househusbands (Quezon City, University of the Philippines-University Center for Women's Studies). 
Rodriguez, R. M. (2002), 'Migrant heroes: Nationalism, citizenship and the politics of Filipino migrant labor', Citizenship Studies, 6(3), 341-356. DOI $10.1080 / 1362102022000011658$

Rodriguez, R. M. (2010). Migrants for export: How the Philippine state brokers labor to the world. (Minneapolis: U of Minnesota Press).

Scammell, J. (1993), 'The Formation of the English Social Structure: Freedom, Knights, and Gentry, 1066-1300', Speculum, 68(03): 591-618. DOI 10.2307/2864967

Scott, J. (1985), Weapons of the Weak: Everyday Forms of Peasant Resistance. (New Haven, CT, Yale University Press).

Silvey, R. (2004), ‘Transnational Domestication: State Power and Indonesian Migrant Women in Saudi Arabia', Political Geography, 23:245-64. 10.1016/j.polgeo.2003.12.015

Silvey, R. (2006), 'Consuming the Transnational Family: Indonesian Migrant Domestic Workers to Saudi Arabia', Global Networks, 6(1):23-40. DOI 10.1111/j.14710374.2006.00131.x

Strobl, S. (2009), 'Policing Housemaids: The Criminalization of Domestic Workers in Bahrain', British Journal of Criminology, 49(2):165-83. DOI 10.1093/bjc/azn071

Vlieger, R. (2011), Domestic workers in Saudi Arabia and the Emirates: a socio-legal study on conflicts (Amsterdam, University of Amsterdam, $\mathrm{PhD}$ thesis).

Vlieger, R. (2012), 'Domestic Workers in Saudi Arabia and the Emirates: Trafficking Victims?', International Migration, 50 (6): 180-94. DOI 10.1111/j.1468-2435.2012.00785.x

Wood, A. (1990), Hegel's Ethical Thought (Cambridge, Cambridge University Press).

Yates, L. (2015), 'Rethinking prefiguration: Alternatives, micropolitics and goals in social movements', Social Movement Studies, 14(1), 1-21. DOI 10.1080/14742837.2013.870883 